\title{
Network Transitions on a Contested Periphery: From Prestige Goods to Bulk Goods (or not) in Northeastern North America, 1600-1760
}

\author{
Jonathan Leitner \\ ileitner@yahoo.com
}

\begin{abstract}
This paper examines the Euro-Indigenous fur trade in northeastern North America, following Carlson's use of Chase-Dunn and Hall's nested interaction networks to examine a similar trade during roughly the same time period on the continent's other side. These network interactions took place on what became a contested periphery, and they shaped the development of states and the modern world-system, with Europeans contending with each other and with Native Americans for political and economic control, and at times mere survival. European politicalmilitary networks were essential to maintaining colonies, and in contrast to what the general interaction networks model posits, these were made up of or at least coterminous with nested prestige goods networks. Europeans were initially dependent upon prestige goods networks with Native Americans; indeed, the French political military network in North America was arguably formed by (or at least supported by) the various Franco-Indigenous prestige goods networks. The French, Dutch, and British all attempted to transition their colonial economies from the extractive economies and low settler population densities typically associated with prestige goods networks to the agricultural economies and higher settler population densities of bulk goods networks. The paper traces the attempted colonial interaction network transitions from contested peripheries within Euro-Indigenous prestige goods networks to settled colonies within bulk goods networks and firmly within a given core powers' imperial political military network. The success (or failure) of these network transitions helped determine the Euroamerican colonies' geopolitical futures in the world-economy, as well as those of their indigenous neighbors and their struggles for physical survival and political sovereignty.
\end{abstract}

Keywords: Exchange networks, fur trade, colonialism

In his works examining northwestern North America's Euro-indigenous fur trade, Carlson (2002; 2012b:37-74) adapts Chase-Dunn and Hall's (1997) nested networks of interaction, which he treats "as various "states of being' through which a given region passes" (Carlson 2002: 391). The four networks - information (IN), prestige goods (PGN), political-military (PMN) and bulk goods (BGN) - represent interregional exchange/interaction structures, of which "[w]orldsystems are fundamentally composed," are cast at decreasing geographical scale (Chase-Dunn and Hall 2012: 188). INs and PGNs are widest, having the lowest transport costs relative to the weight and value of the goods exchanged, and involving the least formal world-systemic 
incorporation; PMNs are smaller, with increasing degrees of formal incorporation; BGNs are smallest, due to relatively high transport costs, and are wholly within a given PMN (Chase-Dunn and Hall 1997: 52-55; 2012: 188-89; Carlson 2001:244-45; 2012a: 90).

Nested interaction network analysis allows for comparisons of world-systems, facilitating the extension of world-systems analysis to potentially any pre-1500 CE timespace (Chase-Dunn and Hall 1997; Denemark et al. 2000; Chase-Dunn and Anderson 2005). Yet it is also useful for understanding the modern world-system (e.g., Wallerstein 2004: 23-41). Carlson (2002: 390; 2011a: 165) posits that studying world-systemic regional incorporation in terms of interaction networks resolves the methodological difference between Wallerstein's "European, state-centric, 'inside-out" approach and Hall's "external, indigenous peoples, "outside-in" approach. Hall himself suggests comparative studies of incorporation "along the edge of each" of the four types of interaction network (2012: 51-52), as well as a focus on more regional, and even local processes, by way of finding out how world-systemic processes work at local levels, and in turn how a place and its processes comprises part of a world-system (Hall 2009:36). Therefore, I focus on regional change in light of nested interaction networks, in particular how regions move from one interaction network to another, and attempt to balance between indigenous and European actors.

Analyzing the Pacific Northwest fur trade, Carlson (2002) is most concerned with INs and PGNs; he shows that fur's relatively high value attracts interest from the core and "hooks" the external region to the world-economy, "financing the initial expansion of the system" into the new region, "and then subsidizing the [region's] increased incorporation [...] by offsetting otherwise prohibitive 'start-up' costs associated with colonial expansion" (2002: 410). If profitable, a PGN is soon included in a PMN, with the beginning of colonial expansion (Carlson 2002: 418-19). Moving further up the network scale, this paper will also examine attempted transitions from PGN and PMN to BGN. In northeastern North America ca. 1600-1760 (see Fig. 1), Europeans were similarly attracted by the promise of prestige goods trade in fur, ${ }^{1}$ which in turn "primed" the region's indigenous peoples, subjecting them to "[i]mportant social, political, and economic changes...well before" formal incorporation (Carlson 2012a: 88). The three competing European powers each quickly established formal colonies, which especially at first depended on good political and trade relations with neighboring indigenous peoples (Richter 2001; Baker and Reid 2004; Parmenter 2007). These relationships developed into PGNs, within which European-Indigenous relations were marked by mutual dependence, as native peoples learned to appreciate European manufactured goods' quotidian usefulness (Trigger 1991) while European colonials relied on natives as both fur suppliers (Kardulias 1990) and proxy military forces (Baker and Reid 2004; Parmenter 2007). Externality, peripherality, and incorporation were in fact highly - and often formally (Richter 1988; Hagedorn 1995; Meuwese 2003) negotiable in this particular world-systemic time-space (cf. Dunaway 1996b; Carlson 2001: 245, 2011a: 166, 192; Kardulias 2007: 66-76).

\footnotetext{
${ }^{1}$ Fur, admittedly, is not always nor necessarily a prestige good. For example, North American deerskins in the $18^{\text {th }}$ century had become an industrial input in Europe (Dunaway 1994: 226-27; 1996a: 32-33; Richards 2003: $497-$ 502).
} 
Figure 1: Indigenous Nations and European Settlements

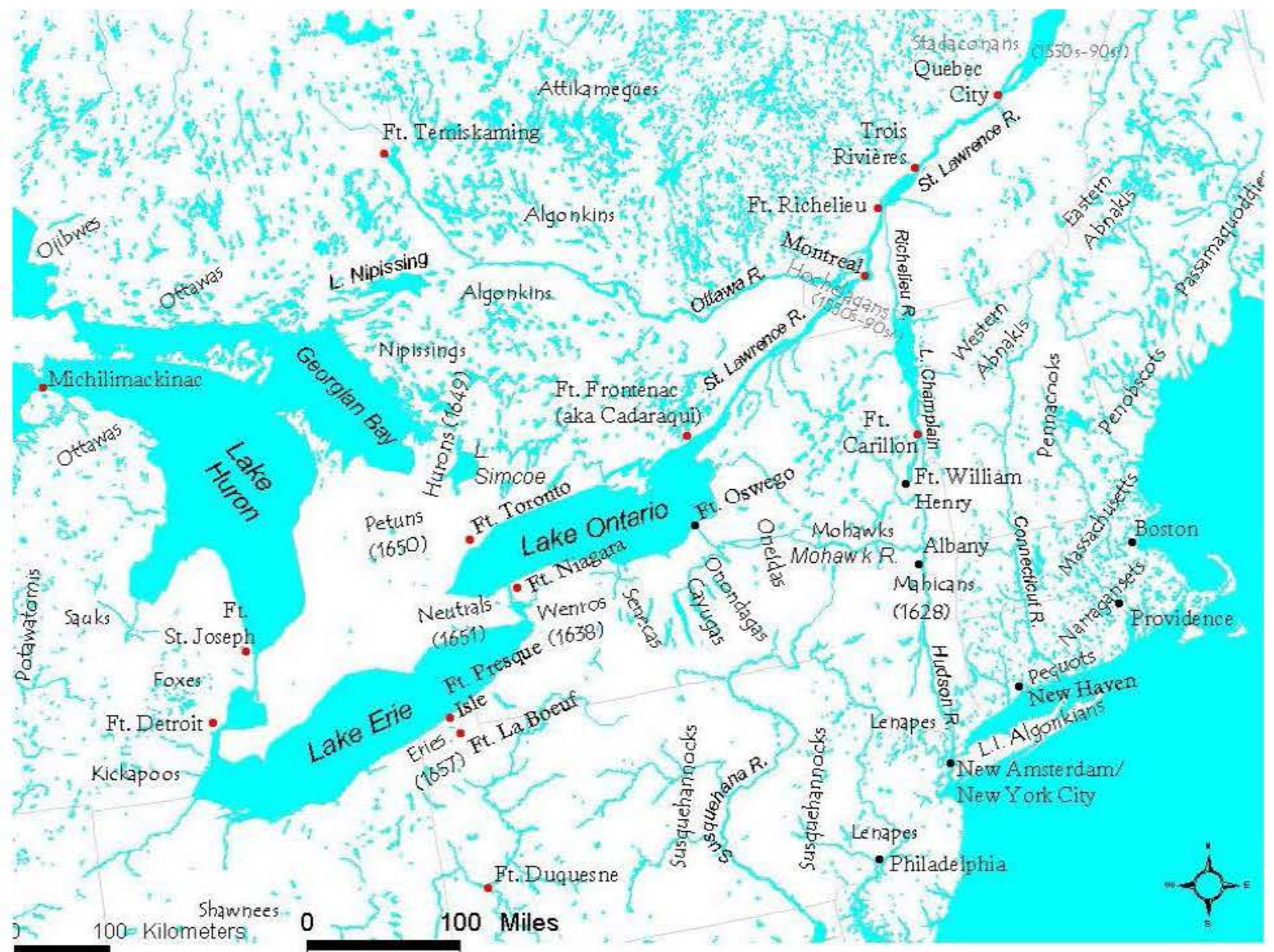

Indigenous national locations as of early $17^{\text {th }}$ century. Dates refer to year of defeat/dispersal by the Haudenosaunees; French settlements in red, British in black. Maps consulted: Delâge (1993: xii); Jennings (1984: 15, 26); Richter (1992: 16, 63, 146-47, 2001: 65, 165); Trelease (1997: 6, 13, 119); Trigger (1985: 150). Digital data sources: ESRI; geogratis.cgdi.gc.ca.

In the same sense that incorporation develops along a continuum (Chase-Dunn and Hall 1997: 61-64; Carlson 2001: 247-50; Hollis 2005: 96-99), and can grow stronger or weaker over time as it is contested (Dunaway 1996b; Bush 2005: 87, 90), a regional transition from one network to another follows a similar path. We will explore the tensions contained in these transitions, in particular from PGNs to BGNs, and how these, with their typically informal boundaries, may either support or undermine political-military networks which typically have more formal boundaries (Hall 2013: 27). Part of the tension in this case was because northeastern North America was also a contested periphery, "a region in the interstices between major states over which the latter fight for control" (Kardulias 2007: 64). While the concept was developed for and more typically used in analyzing ancient, typically non-capitalist world-systems (e.g., Chase-Dunn and Hall 1997: 37; Cline 2000: 7-8; Hall 2005: 108-09), I use a state-based definition because in this case, the contested periphery was not just between world-systems but also between core states contending for hegemony within a world-system (Leitner 2005). Over the course of the paper we will therefore also examine the different imperial goals and competing models of colonialism that each of these core states attempted to apply to the contested periphery, which in turn gave their subjects (and chartered firms) varying incentives to trade, to 
settle and farm, or otherwise interact with Indigenous people and other Europeans. Their geographic location made Indigenous peoples the pivot: collectively outnumbering the Europeans for many decades and possessing the knowledge necessary for both furbearer hunting and initial fur preparation, several indigenous groups proved themselves invaluable by providing relatively cheap, undercompensated labor and military power to the Europeans - but also resisting both particular European colonies and the general project of European expansion (cf. Hall 1989; 2005: 95; Fenelon 2012).

But any comparisons made between European colonial praxes, or between IndigenousEuropean relations in northeastern North America in the $17^{\text {th }}$ and $18^{\text {th }}$ centuries are unavoidably what McMichael (1990) has identified as "incorporated comparisons," given the relatively close time-spaces and the context of world-economic competition between their respective metropoles (cf. Adelman and Aron 1999: 817). Incorporated comparison generally entails "giv[ing] substance to a historical process [...] through comparison of its parts," or alternately via "comparative analysis of "parts' as moments in a self-forming whole" (1990: 386; cf. Bush 2005: 104), while at the same time recognizing that the parts can be compared because their historical connection makes them "mutually conditioning" with comparisons that can be either cross-space, cross-time, or both (McMichael 1990: 393; 2000: 671).

In general, European traders hooked themselves into the continent's "pre-existing exchange networks" (Delâge 1993: 82-83; Hollis 2005: 107; Kardulias 2007: 68), similar to an earlier European strategy in Asia (Abu-Lughod 1989: 361). But the colonial strategies differed regarding what types of interaction networks of which the colonies should ultimately be part. Mostly controlled by a merchant company more concerned with trade than settlement, New Netherland was never secure in the Dutch PMN, nor fully integrated into any BGNs. Arguably this was due to the United Provinces' trade-focused imperialism, though there was a weak attempt to preserve political control by promoting private agricultural settlement. The British authorities in New Netherland's successor colony, New York, came to understand the ostensible PGN with the powerful Iroquois League (a.k.a. the Haudenosaunees) as a political-military matter, eventually resulting in formal diplomatic ties. Yet, the colony became part of a BGN with the other mainland colonies and the Caribbean, due to the longstanding, albeit general, British colonial strategy focusing on agricultural settlement and imperial economic integration. The French in New France/Canada relied most on PGNs with their indigenous allies to buttress the colony's place in their PMN, along with a less-successful attempt to institute a BGN between Canada and their own Caribbean colonies. Attempted bulk goods transitions in all three colonies were initially contested by those who placed more importance on profitable trade and who resisted competition from small farmer-traders.

Though arguably "born capitalist" (Dunaway 1996a: 16), as semiperipheral enclaves on the edge of a still largely external zone of the world-economy these European colonies were all highly dependent for varying periods on prestige goods trade and concomitant political-military alliances with indigenous groups, as well as indigenous labor, due to their own relatively small populations. Eventually the relationship tipped: Europeans gained strength, especially those European colonies that opted for bulk goods production and trade, while indigenous peoples grew weaker and more dependent on European support (Richter 1983: 540-42; Jennings 1984: 111; Trigger 1985: 165), and were gradually incorporated along with their land and resources into the world-economy (cf. Carlson 2001: 246-50; Hall 1989: 18-22). The European colonies' political and economic futures in turn depended on transitioning from prestige goods trade with indigenous peoples to bulk goods production and trade with each other. This paper will trace 
these attempted transitions from PGN to PMN and then BGN (or not), by way of Dutch, French, and Anglo-British attempts to win control of the contested periphery, alongside indigenous peoples' attempts to maintain sovereignty, or at least negotiate the terms of their incorporation.

\section{New Netherland and its Indigenous Neighbors, 1609-1664}

Following the European beaver's (Castor fiber) late $16^{\text {th }}$-century decline, its cousin Castor canadensis became the primary species in the $17^{\text {th }}$-century North American fur trade (Wolf 1997: 159). Both species' inner fur is barbed, allowing hairs to interlock, making it easy for European hat makers to craft the felt fabric for men's high fashion hats, ca. 1550-1850 (Norton 1974: 104; Eccles 1983b: 19-20; Richards 2003: 467-68). In analyzing the Canadian colonial fur trade, Innis (1970) argued that beaver fur's relatively high value and low European labor requirements (since Indigenous peoples did much of the trapping and curing work; Eccles 1983b: 19; Kardulias 2007: 70) had significant developmental consequences in parts of North America due to its nonpromotion of European immigration and agricultural settlement. PGNs typically relied on indigenous labor and thus didn't require large settler/slave populations as BGNs generally did (Wolf 1997: 129-353). Such was New Netherland's basic experience, with concern over its low European population leading to great dependence on its indigenous neighbors, as well as to more liberal settlement terms for private colonists, neither of which prevented an eventual English conquest.

\section{The Dutch-Lenape PGN, 1609-1620s}

A high-value input for an artisanal product, North American beaver fur was not part of the bulktrading mercantile-industrial-financial complex that made the Netherlands a core nation-state, and eventually a hegemonic one (Bunker and Ciccantell 2005: 104-22; Özveren 2000: 28-37). It was riskier and higher-cost than the Baltic "mother trade," yet still quite profitable (Rink 1986: $35,209)$. Those profits were arguably generated by the intersection of geography - the network of rivers and lakes that formed Indigenous trade routes and suppressed transport costs (Innis 1970; Richards 2003: 466) - with typically ill-compensated Indigenous labor (Delâge 1993: 78162; Kardulias 2007).

The Algonkian-speaking Lenapes of the lower Hudson and Delaware Valleys were the first indigenous North Americans to trade extensively with the Dutch, and were soon using European consumer goods (e.g., liquor, cooking utensils, cloth goods, steel knives, and axes), and internally competing for fur (Kraft 1986: 155-59, 198-211; Rink 1986: 35; Trelease 1997: 11). The trade in turn generated demand for sewan/wampum, a seashell currency made by coastal Algonkian peoples (Ceci 1990: 50). Prohibited from coining money, New Netherland authorities legalized wampum as a medium of exchange, along with beaver pelts and tobacco (Kraft 1986: 202-03; Ceci 1990: 55, 59-60; Delâge 1993: 280). Pre-contact, wampum's use was more likely ceremonial and diplomatic (cf. Ceci 1990: 49-50; Abler 1992: 164). However, as fur gathering for Europeans became "craft specialized" - i.e. the existing practices for hunting, trapping, and preparing furs were consciously intensified by indigenous peoples because of their involvement in the Europeans' market economies (Kardulias 1990: 25, 31, 52; 2007: 66-67) the trade in turn required a specialized currency, as is typical in MWS-era regional incorporation (Hopkins and Wallerstein 1987: 772-73). 
Incorporation into the MWS has also entailed specialized production replacing subsistence among indigenous men (Carlson 2001: 242; 2002: 427; Kardulias 2007: 68), which doubly burdened women, who retained their subsistence responsibilities alongside fur preparation work (Dunaway 1996a: 37-38; Richards 2003: 507). This basic model describes the Lenape experience (see Burrows and Wallace 1999: 12-13; Kraft 1986: 138-43, 200). The Dutch also attempted to convert the Lenapes to "stateness" (Carlson 2001: 37-38) by appointing male "chiefs" to manage the trade (Kraft 1986: 201), though the focus of politics onto a smaller number of males decreased women's political participation (Dunaway 1996a: 17, 37, 1996b: 461; Hollis 2005: 117, 119).

\section{Dutch PGNs with the Mahicans and Mohawks, 1620s-1650s}

By the mid-1620s, Lenape territory was severely depleted of fur-bearing mammals (Kraft 1986: 199 ), and by the mid-1630s their population had been reduced by 90 percent from pre-contact (Trelease 1997: 184-85; Burrows and Wallace 1999: 37). Dutch traders soon focused on presentday Albany, 150 miles up the Hudson River (Burrows and Wallace 1999: 22; see Figure 1), where they had established the trading post Fort Nassau (later Fort Orange), ca. 1614-15. The post allowed easier access to fur supplies, traded by the then powerful Mahicans, Algonkianspeakers who in turn traded with other Algonkian peoples further north and east. For the Mahicans, Fort Nassau assured them of a market for their furs (Gehring and Starna 1992: 12-13; Trelease 1997: 31-33). When the Dutch West India Company (GWC) took over New Netherland in 1621 , they also had a more stable trading partner.

The GWC was a prime example of private interests "being used to fund the exploitation of primarily luxury goods, in place of official political-military expansion on an empire's frontier" (Carlson 2002: 413; cf. Hollis 2005: 111). But it also had very state-like attributes, including judicial, treaty-making, and military authorities, as well as a trans-Atlantic trade and navigation monopoly (Klooster 2002: 172). Chartered in 1621, the GWC was part of the Dutch grand strategy to use overseas merchant firms militarily against Spain and Portugal (Bachman 1969: 25-26, 53; Boxer 1990: 26-28, 54). Since New Netherland was entirely beyond Spain's sphere of influence, and lacked a military justification, reliable fur trade profits were the colony's raison d'être, offseting risky plans to conquer Brazil and Peru (Condon 1968: 60; Bachman 1969: 25, 55; Rink 1986: 65, 89-90). Focused on prestige goods trade, the GWC discouraged independent agricultural settlement to avoid complicating Euro-indigenous relations; the company instead emphasized peaceful coexistence with indigenous peoples, as well for reasons of "common prudence" (Bachman 1969: 59, 83; Rink 1986: 78; Trelease 1997: 37-42). ${ }^{2}$

For their part, the Mahicans "probably saw [...] the advantages of controlling access" to the Dutch and their trade goods (Gehring and Starna 1992: 13-14). Dutch-Mahican coexistence around Fort Orange was nonetheless marked by quarrels and occasional violence, "but always renewed through trade" (Jennings 1984: 50-51). GWC policy toward native peoples was a matter of relative power: while generally solicitous of stronger groups, e.g., the Mahicans and then the Mohawks, who were inland and controlled larger fur supplies, company agents were more hostile toward the weaker coastal peoples, particularly the Lenapes as they lost standing in the

\footnotetext{
${ }^{2}$ The GWC Board instructed its local managers to compensate native peoples for voluntarily ceded land, though generally ignoring "fundamental issues" of Indian ownership, substantive land values beyond the purchase price, and the Indians' post-sale reserved rights (Starna 2003: 16).
} 
fur trade (Trelease 1997: xiii, 115). ${ }^{3}$

Despite generally peaceful relations with the Dutch, the trade probably caused changes in Mahican life similar to those that affected the Lenapes (Dunn 1994: 76-77, 86-87), but a weak archaeological record prevents firm conclusions (Starna 2003: 13). More certain is the Dutch presence at Albany after 1614-15 attracted the Haudenosaunees (Richter 1992: 88), in particular their easternmost nation, the Mohawks. ${ }^{4}$ In conflict with the French and their various indigenous allies, the Mohawks looked to trade with the Dutch, but had to first defeat the Mahicans to do so (Trigger 1985:173-76; Richter 1992:54-55; Brandão 1997: 62-71). Following their conflict with the Mahicans (ca. 1624-28), the Mohawks were soon actively trading with the Dutch (Trigger 1971: 277-82; Jennings 1984: 49; Gehring and Starna 1992: 16-18). After a brief interruption, New Netherland's fur exports rebounded (see Table 1) and its economy grew dependent upon the GWC-Mohawk relationship, as each became the other's chief trading partner.

Table 1: New Netherland's Furbearer Exports, 1624-36

\begin{tabular}{|c|c|c|c|c|}
\hline Year & $\begin{array}{r}\text { Beaver } \\
\text { pelts }\end{array}$ & $\begin{array}{r}\text { Otter pelts } \\
\text { (\& others, } 1626, \\
' 28, ' 33)\end{array}$ & $\begin{array}{r}\text { Total } \\
\text { returns } \\
(\text { in } f)\end{array}$ & $\begin{array}{r}\text { Return } \\
\text { per skin } \\
\text { (in } f)\end{array}$ \\
\hline 1624 & 4,000 & 700 & 27,125 & 5.77 \\
\hline 1625 & 5,295 & 436 & 35,825 & 6.25 \\
\hline 1626 & 7,258 & 857 & 45,050 & 5.55 \\
\hline 1627 & 7,520 & 370 & 56,420 & 7.15 \\
\hline 1628 & 6,951 & 734 & 61,075 & 7.95 \\
\hline 1629 & 5,913 & 681 & 62,185 & 9.43 \\
\hline 1630 & 6,041 & 1,085 & 68,012 & 9.54 \\
\hline 1632 & 13,513 & 1,661 & 143,125 & 9.43 \\
\hline $1633^{*}$ & 8,800 & 1,383 & 91,375 & 8.79 \\
\hline $1634-35$ & 14,891 & 1,415 & 134,925 & 8.27 \\
\hline$\frac{1624-35}{\underline{\text { totals }}}$ & $\underline{80,182}$ & $\underline{10,948}$ & $\underline{725,117}$ & $\underline{7.96}$ \\
\hline $1636 * *$ & ca 8,000 & & & \\
\hline
\end{tabular}

${ }^{3}$ Indeed, the GWC's local director instigated a brutal conflict with the Lenapes in the early 1640 s, who lost nearly 1,000, but destroyed many European farms and settlements; many colonists fled to Europe (Rink 1986: 215, 217, 258; Trelease 1997: 70-83; Meuwese 2003: 409-16). Similarly, the period 1655-64 was marked by steady conflict with indigenous peoples on Long Island and the lower Hudson Valley (Richter 1992: 96).

${ }^{4}$ The other four nations are the Oneidas, Onondagas, Cayugas, and Senecas. The Tuscaroras, ethnic Iroquoians from the Carolinas, joined in the mid-1700s. 
New Netherland's May-November trading season was the same as the Haudenosaunees' diplomatic/gift exchange season; the trade also fit with the latter's seasonal round, subsistence work, and sexual division of labor (Richter 1992: 76). Despite suspecting they were being cheated (Brandão 1997: 88), the Mohawks kept trading with the Dutch largely because of the predictably negative consequence of craft specialization (Kardulias 2007: 66-67,73); by the mid1630 s trade goods had replaced traditional craft goods, but craft skills were not necessarily being passed on, making the Haudenosaunees dependent on the Dutch trade for their survival (Jennings 1984: 61; Trigger 1985: 315; Burke 1991: 289; Richter 1992: 86-90). They also acquired European diseases that killed nearly half their population, which dropped from 22,000 in 1630 to 12,200 in 1640 (Mancall, Rosenbloom, and Weiss 2002: 35). After an initial 1634 epidemic, the Mohawks alone declined from 8,100-10,000 to 2,000-4,500 (Snow and Lanphear 1988: 24; Starna 1991: 246).

Yet the Dutch were as dependent in turn on the Mohawks' military capacity, leading the GWC to start trading them firearms in the mid-1640s (Trigger 1971: 281-86; Jennings 1984: 55 57, 71, 102; Richter 1992: 93-95; Brandão 1997: 100). The Haudenosaunees' precise strategy in the 1640s-50s is still debated (Abler 1992; Brandão 1997: 84-88; Starna 2003: 24-27), but included: raids on fur shipments to the French (Trelease 1962; 1997; Trigger 1971; 1985; Richter 1983); conquests of new hunting territories in western New York, Ontario, Michigan, and the Ohio Valley (Brandão 1997; Starna and Brandão 2004); and conquests of other indigenous peoples for captives to replace population losses from both war and disease (Richter 1992; Schlesier 1976). As well, fur supply strategies apparently varied by nation: the Mohawks emphasized raiding and piracy, while the Senecas were territorially expansionist (Abler 1992: 158-59).

Haudenosaunee victories expanded New Netherland's fur supply: 1656-57 saw the largest fur volume in the colony's recorded history, with some 46,000 beaver and otter pelts shipped each year from Fort Orange to New Amsterdam (Trelease 1997: 131), a dramatic increase over the 1624-35 total (see Table 1). Yet by 1660 there was a sudden decline to 1520,000 pelts (Burke 1991: 284; Fernow 1877-87: XIV, 444). Stimulated in part by furbearer depletion in their homelands (Abler 1992: 158), the Haudenosaunees' political-military expansion engendered conflicts with neighboring Algonkian nations, reducing time spent on hunting/trapping (Thomas 1981: 364), and putting New Netherland into fiscal deficit (Fernow 1877-87: XIII, 372-73; Trelease 1997: 131).

The Haudenosaunees suffered additional blowback. Their success against France's Indigenous allies also threatened the PGNs responsible for Canada's "economic prosperity" (Trigger 1985: 273), and compelled Versailles to make it a royal colony in 1663, as well as increase its military commitment. Other indigenous nations acquired firearms by the early $1660 \mathrm{~s}$, and the Haudenosaunees suffered greater losses in future conflicts (Jennings 1984: 102; Trigger 1985: 271-73; Richter 1992: 62, 98). Disease and warfare further reduced their collective population from 10,000-12,200 (1640s) to 8,600-8,700 (1670s) (Richter 1983: 543; cf. Brandão 1997: 158ff, Tables C3, C5; Mancall et al 2002: 35). Population losses and the decaying Dutch trade led most of the Haudenosaunees to a post-1664 rapprochement with the English (Jennings 1984: 130; Trelease 1997: 228); the Mohawks in particular became their loyal ally (Parmenter 2007). 


\section{New Netherland's End, 1650s-1664: Geopolitical Limits of a Prestige Goods Economy}

An irony of Dutch hegemony was the loss of its American colonies in the mid- $17^{\text {th }}$ century, in part because the Netherland's relatively high living standards and high direct costs for migrants limited any push to colonial emigration (Rink 1986: 97-105; Delâge 1993: 241-44; Jacobs 2005 : 45-47). Many New Netherlanders were in fact not Dutch (Rink 1986: 139-71), a characteristic of several other Dutch colonies (Boxer 1990: 230, 245-46). This, along with inadequate defenses, contributed to the GWC losing its major holdings during 1648-64 (Kammen 1975: 88). This was not for lack of sound policy intentions; Dutch officialdom increasingly wanted to switch the colonial economy from prestige goods production to bulk goods production, in particular grain, to supply the GWC's other colonies and possibly replace Baltic grain and timber in the metropole and provide a strategic population of agricultural settlers (Bachman 1969: 57-71, 148; Rink 1986: 134; Jacobs 2005: 112-13, 214-15). The GWC's liberalization policies - allowing private estates in the Hudson Valley in the late $1620 \mathrm{~s}-30 \mathrm{~s}$, and then smaller private settlers from the 1640s onward (Bachman 1969) - did increase New Netherland's population from 500 in 1640 to 2,500 in $1645,3,500$ in 1655 , and then near 9,000 by 1664 (Kammen 1975: 38; Rink 1986: 158, 164). This figure still dramatically trailed that of its English neighbors, however, with Virginia at 40,000 and New England at 50,000 (Bachman 1969: 131; Kammen 1975: 38; Rink 1986: 121-25, 158). Sound policy intentions were stymied by the logic (however delimited by world-systemic structures and processes) of individual choice in weighing the relative costs of migration (cf. Hall and Kardulias 2010: 31).

This was particularly true in comparison to contemporary English migrants. Lower living standards and a period of rural primitive accumulation as the agricultural economy became commercialized left a large number of poor, landless people desperate enough to migrate. This produced a mid- $17^{\text {th }}$-century flood of English immigration "that completely upset the existing balance of power in North America" (Eccles 1983b: xii; Delâge 1993: 241, 244). The style of settler colonialism brought whole communities of émigrés, rather than a relative handful of corporate employees or government officials as with other colonial powers (Chase-Dunn 1980: 197-98). ${ }^{5}$ Though never a formal policy and with a fair amount of regional variation along the coast (Earle 1992; Hornsby 2005), the basic style of English North American colonization stemmed from the model propounded in the late $16^{\text {th }}$ and $17^{\text {th }}$ centuries by the cousins Hakluyt, who advocated a type of agriculturally productive settler colonialism to provide England with staple (bulk) commodities, and a safety valve for its unemployed masses, and an "oblique" geopolitical challenge to the Iberian colonies (Earle 1992: 481). From the standpoint of worldeconomic competition, the Hakluyt model helped meet England's need for both external markets and raw materials (Wallerstein 1980: 103; and see below).

New Netherland's location midway between two burgeoning English colonies also hindered the Navigation Acts (Delâge 1993: 269; Burrows and Wallace 1999: 72), England's challenge to Dutch hegemony via "state constraint on foreign merchants" (Wallerstein 1980: 76, 96, 236). An English New Netherland could also be developed for a bulk goods trade with the Caribbean, sending slaves and food for raw sugar and molasses (Burrows and Wallace 1999: 72). England's "new merchants" who assumed political power in the $17^{\text {th }}$ century clearly saw it as

\footnotetext{
${ }^{5}$ This had the concomitant effect of introducing a population of children that was "susceptible and possibly infected" with diseases like smallpox, hence the 1630s epidemics among the northeast's indigenous peoples (Snow and Lanphear 1988: 27-28).
} 
part of a BGN, modeled on their other mainland North American colonies (Brenner 2003: 16162, 170). New Amsterdam's merchants in fact started a bulk goods trade with its English neighbors and the Caribbean in the 1640 s, when it was still legal; after the 1664 conquest they fit easily into the mainland-Caribbean BGN (Matson 1998: 17, 36-117).

\section{New France's Euro-Indigenous PGNs, 1600-1663}

Similar to New Netherland, Canada ${ }^{6}$ was initially controlled by trading companies, whose fur intake and subsequent profits depended on Indigenous peoples' labor and pre-existing trade networks. Though both PGN-dependent colonies, there were some notable differences. Unlike New Netherland, which had little missionary activity, the Franco-indigenous fur trade came to be dependent on missionary activity, and was nearly ended by it (Delâge 1993: 117-19, 166-67, 223-24). And while New Netherland's state-chartered monopoly gradually liberalized the economy, New France's state-chartered monopoly gave way to state control in 1663, albeit due to similar concerns: low European population, a stagnant economy, and possible English encroachment (Eccles 1983b: 57; Trigger 1985: 283; Choquette 1997: 252-53). Though the Franco-Indigenous PGN was successful up to a point in supporting and even extending France's PMN in North America, like Dutch New Netherland it began to fall behind Britain's BGNfocused colonies.

A formal French presence began in the St. Lawrence Valley soon after 1600 (Eccles 1983b: 20). Versailles wished to promote settlement (Moogk 2000: 13), but official opinion was divided: some wanted to promote settler agro-colonization and ultimately integrate the colony into a BGN (like the English); while others wanted to keep out large-scale European settlement and develop a profitable fur trade with the region's indigenous peoples, i.e. a PGN model (akin to the Dutch). The PGN model carried the same contradiction as faced the Dutch: low European population meant geopolitical vulnerability, something acknowledged even by those with an interest in a PGN-focus for the colonial economy (Trigger 1985: 315-16). In other words, to keep the colony and its fur trade in France's PMN, a BGN would have to exist alongside a PGN. But before 1663, the state contracted with undercapitalized private firms (Bumsted 1992: 69), yet all of these were focused on the fur trade (Eccles 1983b:34), and not on promoting agricultural settlement d̀ la the Hakluyt model (Delâge 1993; Choquette 1997: 247-77). Partly this was because fur trade profits were not large enough to support major colonization. Also, in spite of formal obligations, trading companies were unwilling to promote even modest colonization, fearing competition from many small private traders (Trigger 1985: 306, 315). Mid-1 $7^{\text {th }}$-century Canada was therefore still both economically and politically dependent on its Euro-Indigenous PGNs.

These PGNs soon became politically complicated. French traders initially preferred dealing with the Montagnais and Algonkins peoples north of the St. Lawrence with easy access to a large volume of putatively higher quality northern furs (Richards 2003: 477, 492; cf. Starna 2003: 25), for which the French traded iron weapons. The Mohawks' technological disadvantage vis à vis the Montagnais and Algonkins, and French unwillingness to deal with them, compelled them to trade with the Dutch (see above). After several decades indirectly receiving European

\footnotetext{
${ }^{6}$ During the 17th century, France's St. Lawrence Valley colony was interchangeably referred to as either Canada or New France. By 1700, New France came to mean all French North American territories: Canada, Acadia, Louisiana, and the western posts (Eccles 1983b: xvii).
} 
goods, the Hurons bypassed their Algonkin and Montagnais trading partners to contact the French directly in 1609, who promoted an anti-Haudenosaunee alliance with all three nations (Trigger 1985: 139-41, 162-63, 173, 308; Delâge 1993: 82-83).

The inability or unwillingness of either private interests or the state to undertake largescale agricultural settlement in the St. Lawrence Valley made religious orders, in collaboration with merchants, key players in the French colonization strategy (Bumsted 1992: 72; Delâge 1993: 119). Unlike other orders, the Jesuits regarded settlers as a bad influence and accepted native cultures on their own terms, at least to promote conversion (Eccles 1983b: 26; Trigger 1985: 200-01, 316, 320-21; Moogk 2000: 21, 28, 34-35). They accepted French traders, whose presence among the Hurons aided the Jesuits; traders in turn charged indigenous Catholic converts lower prices for European goods, and provided them firearms after 1641 (Trigger 1985: 255; Delâge 1993: 119, 174, 184, 195; cf. Brandão 1997:332-33n31). The Jesuits therefore used a PGN-based strategy to achieve their organizational goals.

The Jesuits settled among the Hurons in 1634, establishing a permanent mission in 1639 (Delâge 1993: 163-64; Moogk 2000: 30) that ended in 1649, the year Huronia was conquered by the Haudenosaunees. The Jesuits' very success in converting a significant minority to Catholicism severely divided Huron society, which along with increased disease exposure were arguably major causes of the defeat (Schlesier 1976:136-41; Trigger 1985:250-59; Delâge 1993: 88-89, 178-224ff), and in turn a major Jesuit setback. The conquest and subsequent dispersal of the Hurons also impeded France's North American colonial policy. The Hurons were its main Indigenous ally and a major source of New France's fur: production had doubled from 15,000 pelts total before 1630 to 30,000 pelts during $1632-40$, in spite of serious disease mortality (Eccles 1983b: 44; Delâge 1993: 142). The fur volume from Huronia to New France possibly even increased post-1640 (Trigger 1985: 250), with French profits in 1646 at nearly 100,000 livres, rising to about 250,000 livres in 1648 (Eccles 1983b: 44).

Key Huron leaders had accepted the Jesuits' presence for continued access to both French military support as well as their only source of European manufactured goods, which by the 1630s many Hurons believed were absolutely necessary to their way of life (Trigger 1985: 247 48, 258, 265; 1991: 1207; Delâge 1993:97). Ironically, even if the Hurons rejected the Jesuits, the French would likely have still traded with them, due to their own economic and strategic imperatives to maintain a PGN that was vital to colonial survival (Trigger 1985: 229). The Hurons were therefore self-limited in their ability to "negotiate externality" (Carlson 2012a: 90) and in the terms of their incorporation into the world-economy. In contrast, the Haudenosaunees, who harbored very few missionaries before the late 1660s (Abler 1992: 166; Delâge 1993: 32628), did not face religious schisms until later. ${ }^{7}$

Though the Hurons' defeat was a major political and economic setback for New France (Trigger 1985: 335), they soon found a new principal indigenous ally and fur supplier in the Ottawas, located further to the west (Richards 2003: 482-86; see Figure 1). The Haudenosaunees continued pressuring French settlements in the St. Lawrence Valley through the 1650 s, one of the motivations behind the colony's 1663 nationalization, especially given its slow population growth. With only 3,035 colonists in 1663, of whom over 1,300 were regular soldiers (Bumsted 1992: 79; see Table 4), private settlement efforts had failed. By the 1660s, the Euro-Canadians were arguably "losing a war of attrition" to the Haudenosaunees (Bumsted 1992: 79), whose

\footnotetext{
${ }^{7}$ Similarly, other social formations such as Abyssinia in the 1500s and Japan in the late 1500 s-early 1600 s, expelled the Jesuits, among other Roman Catholics, "because of perceived negative impacts associated with "incorporation"" (Carlson 2011a: 182, 192, 2012b: 145-72).
} 
fearsome reputation scared off prospective French immigrants (Eccles 1983b: 38, 87; Moogk 1989: 465-66, 487; Choquette 1997: 282).

At the same time, the traders to whom colonial development had been entrusted were too concerned about short-term fur trade profits to promote large-scale settler colonization (Trigger 1985: 342). The availability of fertile land within France (Moogk 2000: 89-92), Versailles' refusal to admit non-French colonists, the availability of more inviting destinations (Choquette 1997: 282, 304), and as with New Netherland the high $\operatorname{cost}^{8}$ meant that as few as 30,000 settlers immigrated to Canada during the entire French colonial period (cf. Hall and Kardulias 2010: 31). Versailles therefore nationalized New France in 1663 to promote its self-sufficiency and provide a market for metropolitan goods (Eccles 1983b: 60; Moogk 2000: 83) - roughly akin to the Hakluyt model of England's BGN colonies.

\section{Attempted PGN-BGN Transitions in Eastern North America, 1663-1754}

\section{Bulk Goods vs. Prestige Goods in Canada, 1660s-1680s}

The French were also losing to the English in the Americas; by 1700 there were $350-400$ thousand Europeans and Africans in the English colonies versus 70,000 French colonists (Wallerstein 1980: 101-02). Following the Hakluyt model and its emphasis on settler colonization and bulk goods production, England also developed a more robust and higher volume transatlantic trade, while France did not. Its home market was big enough, it "was better off economically than England," and therefore did not have as great a need to develop a foreign/colonial trade (Wallerstein 1980: 104). England's need for foreign trade caused it to need more ships, hence more naval stores, "then products with which to buy the naval stores, then colonial purchasers of expanding manufactures" (Wallerstein 1980: 103-04; similarly, Bunker and Ciccantell 2005: 123-34).

Though concerned about colonial competition (Choquette 1997: 283), French mercantilist policies promoted Caribbean and Canadian growth (Egnal 1998: 122, 128-29, 132). Population growth was a priority; immigration to Canada had been 90 percent male and largely comprised of indentured servants, two-thirds of whom returned to France (Choquette 1997: 10, 309n21; Moogk 2000: 108). Crown-subsidized transportation during 1662-1671 increased Canada's European population from just over 3,000 in 1663 to 7,800 by 1676 (O'Callaghan 1853-61: IX, 126; Moogk 1989: 477-81; Bumsted 1992: 79). These efforts included females from the lower end of the socioeconomic scale, with the expectation they would marry and reproduce. The ensuing natural increase raised the Euro-Canadian population to over 11,000 by 1700 (Harris and Warkentin 1974: 32; Choquette 1997: 175, 236; Moogk 2000: 120).

France's weak navy made its colonies potentially vulnerable to maritime blockade, in turn demanding Canadian agricultural development (Moogk 2000: 83). Small traders - 20-25 percent Canada's adult male labor force up to 1681 - therefore had to be forced out of the fur trade to concentrate on farming (Egnal 1998: 134-35). Senior French officials also wanted to create a Canadian-French Caribbean BGN; fish, wheat, flour, peas, and barrel staves would supplement the islands' own trade in sugar, molasses, and rum with France, similar to the Anglo-

\footnotetext{
${ }^{8}$ Post-1650 the cost was 60-80 livres, almost a year's wages for a French artisan, exclusive of living expenses (Moogk 2000: 108).
} 
American colonial BGN (Eccles 1983b: 62). To supply vessels for the trade, a Crown-supported Canadian shipbuilding industry was planned (Miquelon 1988: 433; Egnal 1998: 154; Moogk 2000: 84).

Yet fur remained the major export (Moogk 2000: 84), and France expanded its fur trade in the late 1660s for geopolitical reasons (Eccles 1983b: 105). Following continued conflict and diplomacy (Brandão 1997: 114-15; Richter 1992: 102-04; Trigger 1985: 280-81, 338-40), a formal peace agreement had allowed the Haudenosaunees to hunt just north of the Hurons' former home between Lake Simcoe and Georgian Bay (Richter 1983: 542). French colonial officials nonetheless regarded these lands and furbearing mammals as their indigenous allies'-and by extension, New France's. The real concern was the Haudenosaunees' trading these furs (and those captured from the Ottawas) at Albany for its higher prices (Richter 1992: 129-30, 137), which also attracted French private traders and allied indigenous traders (Buffinton 1922: 339-41; Trelease 1997: 246-47). New France's colonial authorities therefore established trading posts throughout the Great Lakes and on the Illinois and Mississippi Rivers in the 1670s (Eccles 1983b: 109-10; Richter 1992: 130-31, 138-39; Trelease 1997: 247). This hybrid PMN/PGN took firmer shape in the $1670 \mathrm{~s}-80 \mathrm{~s}$, with explicit politicization of prestige goods trade and use of military power to promote profitable trade (Jennings 1984: 173-75; Brandão 1997: 120). Francebound beaver pelts "doubled from about 70,000 pounds in the mid-1670s to 140,000 pounds in the late 1680s" (Egnal 1998: 134). Fur marketing policies and subsidized prices ensured profitability, but the fur trade's subsequent expansion reduced the available labor supply, hampering the development of the bulk goods economy (Eccles 1972: 84-85; 1983b: 104-05).

\section{New York's Move to a Bulk Goods Economy, 1660s-1680s}

Despite plans in the 1660s for a colonial BGN (Burrows and Wallace 1999: 72), New York until 1685 was under the Duke of York, whose policies initially discouraged it by banning freehold farming (Kammen 1975: 112). The colony remained "a classic satellite" of England, much like Canada vis à vis France: a fur entrepôt with a single dominant port city and little rural settlement which was dependent on the metropole for manufactured goods (Matson 1998: 51). After a brief period of home rule in 1683-85, New York was made a royal colony, inspired by Colbert's nationalization of Canadian colonization efforts. Both powers were thus attempting to formalize their mainland North American colonies' place in the imperial PMNs (Greene 2002: 272; Wallerstein 1980: 237).

Yet New York's colonial authorities recognized several larger trends were afoot: the fur trade's decline by ca. 1680 to a fifth of its mid-1650s peak, alongside an existing east coast intercolonial BGN that included reshipment of Caribbean and southern "bulky unprocessed goods" including timber, tobacco, and sugar from New York to England. They also saw potential for expanding this BGN in response to rising Caribbean demand for foodstuffs. ${ }^{9}$ To better promote and control trade, and in response to the politically powerful "great" merchants' demands, New York's governors passed numerous laws favoring the larger New York City merchants, and in the $1670 \mathrm{~s}-80$ s made New York City the colony's sole port of entry (Kammen 1975: 106; Matson 1998: 95-100; Burrows and Wallace 1999: 84). Though contested by rural interests (Matson

\footnotetext{
${ }^{9}$ Caribbean and Newfoundland demand grew from the late 1680 s, drawing over 60,000 bushels of New York grain annually by 1680 (Matson 1998: 78-80, 89, 92, 95-100; Burrows and Wallace 1999: 84, 87).
} 
1998: 102-06, 230-31), these policy choices had the long-term consequence of helping assure New York City's place as a major port and urban center both in the colonial period and beyond.

\section{Haudenosaunee Networks under Pressure, 1680s-1701}

New York's declining fur trade was partly due to the Haudenosaunees' continued conflicts with the French, Ottawas, and other indigenous allies. Coterminous after 1689 with King William's War among the Euroamericans, the Haudenosaunees intended to protect their expanded hunting territories north and west of Lakes Ontario and Erie (Trelease 1962: 47; Abler 1992: 167-68), but fighting only reduced hunting and trading, and dramatically reduced their population. Haudenosaunee losses were perhaps 2,000 people of 8,600-9,000 total (Mancall et al 2002: 35; Richter 1992: 188, 355-56n60). ${ }^{10}$

The 1701 Albany and Montreal treaties ending the conflict were arguably a diplomatic triumph for the Haudenosaunees, who preserved their right to hunt on part of the western lands (Brandão and Starna 1996: 231-32; Richter 1983: 535). Though vowing future neutrality, they deeded their western conquests to England, accepting a legal fiction of English sovereignty to formally obligate English military assistance (Richter 1992: 212; Brandão and Starna 1996: 228). Since the deed overlooked the Haudenosaunees' loss of exclusive rights to these lands, the English used it to justify territorial claims in the Ohio Valley against the French (Jennings 1984: 212). The Haudenosaunees' PMN - their "covenant chain" of conquests and alliances - was formally placed into England's PMN. ${ }^{11}$

For their part, the French intended to use the Haudenosaunees to block their western allies from Albany's cheaper trade goods and in turn channel the westerner's fur back to Canada, as well as prevent English western expansion via Haudenosaunee proxy (Eccles 1983a: 343-44; Richter 1983: 553; Jennings 1984: 210-11). The French maintained their western PGN despite a post-1701 fur glut and decreasing metropolitan demand, because the trade was the basis for alliances (Eccles 1983b: 124-30; Jennings 1984: 210; Desbarats 1995: 613-15). Without these the English could supplant the French as the western nations' source of European goods and potentially control interior North America, thereby threatening France's PMN in North America (Eccles 1972: 99).

\section{New York in the Mainland-Caribbean BGN, 1690s-1750s}

By the 1690 s, New York had "decisively" shifted its export focus "from furs to agricultural surpluses" (Matson 1998: 116; Norton 1974: 101); by 1720, its economy was seasonally-oriented to the Caribbean export trade (O'Callaghan 1853-61: V, 685-86; Kammen 1975: 169-70; Burrows and Wallace 1999: 122). Conversely, in terms of shiploads, by 1720 Caribbean sugar planters' imports of food, provisions, and draft animals from New England and New York equaled that of English manufactures (Matson 1998: 125). Drawing on a hinterland that included the Hudson Valley, Long Island, New Jersey, Connecticut, and Rhode Island, New York City's

\footnotetext{
${ }^{10}$ Some estimate a decline of over half, from 7,710-12,750 in 1689 to 3,690-6,150 in 1700 (Brandão 1997: 123, 126; Jennings 1984: 206; Trelease 1997: 268-69, 303-06, 323).

${ }^{11}$ Though amongst the Haudenosaunees, the easternmost Mohawks remained the firmest English allies; while the westernmost Senecas often "supported the French, though they were divided into pro-French and pro-English factions" (Abler 1992: 169).
} 
grain and flour exports to the islands rose to 80,000 barrels of flour annually by 1740 (Matson 1998: 215, 266), along with an increasing variety of other goods (Pares 1968: 37). ${ }^{12}$ Returning cargoes chiefly included sugar, rum, and above all molasses, the most profitable (yet bulkiest) Caribbean commodity. In turn, sugar and molasses became the basis of New York City's refining and distilling industries, attracting merchant capital reinvestment in local manufacturing, as happened earlier in Boston and Philadelphia (Pares 1968: 14n4, 25-26, 32-33, 92-119; Matson 1998: 183-84, 202, 260-61; Burrows and Wallace 1999: 120-29).

The Caribbean-mainland BGN spurred New York shipbuilding, again per Boston and Philadelphia's example (Özveren 2000: 42, 45). Six shipyards were founded on Manhattan in the late $1720 \mathrm{~s}$-early $1730 \mathrm{~s}$, producing single-masted sloops and two-masted brigs used in both the coastal and mainland-Caribbean BGNs, and spinning-off related manufactories (Burrows and Wallace 1999: 123). Manhattan shipyards produced 12-22 new vessels each year during the 1720s-1750s, with New York City-registered ships tripling from 53 in 1738 to 157 in 1749 (Matson 1998: 130, 142, 416n138). Though arguably a degraded core activity in this period (Özveren 2000: 81), semiperipheral shipbuilding was nonetheless a "crucial" start for the northern colonies' eventual core emergence (Wallerstein 1980: 241).

New York's population doubled between 1703 and1723 and rose by half again between 1723 and 37 (see Table 2). While attaining a trade surplus in the intercolonial BGNs, like other colonies it could never balance the increasing trade deficit with Britain (Kammen 1975: 166-67; Egnal 1998: 35; Matson 1998: 239). There was also nascent political conflict, as the mainlandCaribbean BGN violated Britain's formal PMN by including French, Dutch, and Spanish colonies (Pares 1968: 58, 64-65; Matson 1998: 267, 270, 286). These conflicting imperatives, among others, engendered a movement for political independence starting in the $1760 \mathrm{~s}$ (Kammen 1975: 337-75; Matson 1998: 283-311; Hornsby 2005: 204-34). New York's traders had nonetheless been able to take advantage of the strategic/symbiotic relationship with the Caribbean colonies, and the colonial economy was able to benefit from involvement in a BGN that would not have been possible or as cost-effective with fewer and/or more distant colonial holdings (cf. Chase-Dunn and Hall 1997: 53-54, 2012: 189).

Table 2: Provincial New York population

$\begin{array}{cr}1698 & 18,067 \\ 1703 & 20,540 \\ 1723 & 40,564 \\ 1731 & 50,286 \\ 1737 & 60,437 \\ 1746 & 61,589 \\ 1749 & 73,348 \\ 1756 & 96,790 \\ 1767 & >120,000 \\ \text { Sources: Howard (2001: 150-51); Matson (1998: 128) }\end{array}$

${ }^{12}$ The list of exports included, e.g., ship's biscuit, naval stores, lumber products, pork, beef, beeswax, and flaxseed. 


\section{The Attempted Canadian-Caribbean BGN, 1702-1760s}

French colonial officialdom promoted the same approach for Canada, but its less successful BGN was partly a matter of its pre-existing economy, which required more metropolitan support than it received, and partly a matter of competition from the productive and successful British "bread" colonies, whose Caribbean BGN also included France's island colonies.

Though mid-St. Lawrence Valley farmers were not focused on cash crop production, Queen Anne's War and subsequent European grain shortages (ca. 1710) boosted demand for agricultural exports from Canada as well as New York to the French Caribbean (Miquelon 1988: $434,442)$. Despite potential profits, the trade proceeded slowly during $1715-25$, with less than a handful of ships sailing either way between Canada and the French Caribbean (Egnal 1998: 143). But cultivated land per capita doubled during 1725-39, and Canadian agricultural production increased dramatically during the $1720 \mathrm{~s}-30$ s (Egnal 1998: 149-50). ${ }^{13}$ Self-sufficient in wheat by the mid-1720s, Canadian authorities shipped large amounts of flour to the French Caribbean in the $1720 \mathrm{~s}-1730 \mathrm{~s}$, sending as many as ten ships per year with grain cargoes worth over 100,000 livres, aided by Versailles' attempts to end smuggling between its islands and Britain's mainland colonies (Egnal 1998: 143, 149, 151). During 1720-1740, Canada's annual food and agricultural shipments to the French Caribbean averaged 4,000-8,000 barrels of flour, hundreds of tons of biscuits, and in some years over 4,000 barrels of peas, plus meat, horses, and wood, in exchange for molasses, rum, and credits to shore up its trade deficit with France (Harris and Warkentin 1974: 37; Miquelon 1988: 435, 439).

Sawmills also increased from ten to seventy during 1710-1739 (Miquelon 1988: 441), as royal bounties in the early 1730s also helped expand Canadian shipbuilding (Lanctôt 1965: 113; Eccles 1972: 123; Harris and Warkentin 1974: 55). Between 1729 and 1742, the Quebec City shipyards built at least nine vessels annually (Egnal 1998: 154, 157). Shipbuilding was expected to promote economic diversification and help the BGN with the French Caribbean (Miquelon 1988: 437; Moogk 2000: 84). Canadian shipbuilding was also meant to decrease France's dependence on Baltic timber supplies (Miquelon 1988: 433), similar to Britain's colonial shipbuilding and naval stores policy (Wallerstein 1980: 217n255, 239-40). The Crown soon opened its own Canadian yards for 500-700 ton ships-of-the-line, which dwarfed any ships built in British North America, and employed up to 200 workers (Lanctôt 1965: 113; Harris and Warkentin 1974: 56). ${ }^{14}$

Besides shipbuilding, yet another British war had Versailles massively increase its Canadian spending, from 500-600 thousand livres annually in the 1730 s to 860,000 livres in 1743, two million in 1745, five million in 1753, and an inflation-driven 30 million in 1759 (Egnal 1998: 159-60). The Crown's North American expenditures indicated the French imperial PMN's subsumption of the Canadian-Indigenous PGN (Miquelon 1988: 439). Yet fur remained Canada's major export at about 70 percent of total value by 1739 , with farm produce at 18 percent, fish and fish byproducts at nine percent, and iron and wood at two percent (Moogk 2000: 84), which may also reflect four crop failures during 1736-43 (Miquelon 1988: 441).

\footnotetext{
${ }^{13}$ Wheat production rose from 282,700 bushels in 1721 to 634,605 by 1739 ; in the same period, cattle rose from 23,888 to 38,821 heads, and flax production increased from 54,650 to 127,219 bushels (Lanctôt 1965: 111-12).

${ }^{14}$ However, private Canadian shipbuilding ceased, and the Royal Quebec shipyards' output was considered to be lower in quality, due to less-skilled labor and inferior raw materials, producing only 14 ships through the $1750 \mathrm{~s}$ (Lanctôt 1965: 113; Harris and Warkentin 1974: 56; Moogk 2000: 85, 294n81).
} 
Canada then plunged into a "debilitating" agricultural depression from the mid-1740s to the early 1760s (Harris and Warkentin 1974: 37). In turn, agriculture, shipbuilding, and related industries "collapsed," further hampered by merchant shippers from Britain's mainland colonies, whose supply hinterlands were more reliable and ocean crossings shorter than the Canadians' (O’Callaghan 1853-61: x, 220-32; Miquelon 1988: 441-42).

\section{Crossed and Deteriorating PGNs, 1710s-1750s}

During its attempted bulk goods transition, ca. 1710-40, Canada's ethnic European population rose from about 18,000 to over 40,000, thanks largely to natural means (Moogk 1989: 464; see table 3). But by "combin[ing] indissolubly economic exchange relations with a network of political alliances" (Adelman and Aron 1999: 820) between itself and the western nations - i.e. its hybrid PGN/PMN - France was able to tenuously control North America between the Appalachians and the Rockies, using just 200-600 local officials in any given year during 171950 (Eccles 1983a: 355).

\begin{tabular}{cr} 
Table 3: Euro-Canadian population \\
\hline 1635 & 135 \\
1640 & 359 \\
1650 & 675 \\
1663 & 3,035 \\
1666 & 5,870 \\
1676 & $>7,800$ \\
1700 & $>11,000$ \\
1713 & 18,119 \\
1714 & 18,964 \\
1734 & 37,716 \\
1739 & $>40,000$ \\
1755 & $\leq 62,000$ \\
1760 & $65-70,000$ \\
\hline
\end{tabular}

Sources: Bumsted (1992: 71, 79); Eccles (1983c: xv, 38); Harris and Warkentin (1974: 32, 36, 37); Lanctôt (1965: 101, 108); Moogk (1989: 464); O’Callaghan (1853-61: IX, 126)

At the same time, Montreal and Albany merchants established their own PGN that ignored PMN boundaries (Jennings 1984: 284). Post-1701, with the Haudenosaunees compelled to share their western hunting lands, Montreal merchants received fur that had gone mostly to Albany, and in turn "swapped to Albany's the furs that came cheaply to Montreal for the 
[British] trade goods that came cheaply to Albany," which were in turn shipped west by the Montreal merchants to be exchanged for more fur (Jennings 1984: 82; Richter 1992: 269). By 1720 , this trade was valued at $£ 10-12,000$ per year (Buffinton 1922: 356; Jennings 1984: 284), and Albany merchants - formally within Britain's PMN - had essentially become part of the Franco-Indigenous PGN (Norton 1974: 97-99; Wien 1990: 311-12).

Though easy and profitable for Albany's merchants, British imperial officials, New York colonial officials, and the Haudenosaunees recognized that the Albany-Montreal trade maintained French influence with the western nations, thereby contributing to the Francoindigenous PGNs that underlay France's PMN in North America - whereas Britain would gain influence if the western nations traded at Albany (Buffinton 1922: 358; Aquila 1983: 139; Eccles 1983a: 352). Despite fur's decreasing economic importance, New York colonial officials encouraged western nations to trade at Albany in the late 1710s (Buffinton 1922: 357), and the westerners brought 323 canoe loads of fur to Albany during 1720-24, up from only 30 during 1716-1720 (Richter 1992: 249). Conversely, despite the greater risk and expense for the Canadian traders, and Versailles' opposition (Wien 1990: 298-99, 313), French colonial officials understood their advantage in a continued Albany-Montreal trade, given how "intertwined" were the PGNs and PMN (Eccles 1983a: 351-52).

The Albany-Montreal trade also cut the Haudenosaunees out of their mediating role between the western nations and the Albany Dutch (Aquila 1983: 79; Jennings 1984: 353; Richter 1992: 250). Losing this role, and having suffered great losses from warfare and disease, the Haudenosaunees became British subjects with the 1713 Treaty of Utrecht (Richter 1992: 234-35). Despite their official post-1701 neutrality, becoming formally part of Britain's PMN was arguably a matter of geopolitical survival. However, it also presaged their further incorporation into the world-economy (Richter 1992: 255-80). Like trading posts elsewhere, Britain's Forts Oswego and Niagara in western New York were "mechanisms of incorporation" (Carlson 2002: 430); by 1740, other than food and shelter, the Haudenosaunees were materially dependent on trade with the two forts (Richter 1992: 268). Besides a general dependence on European goods, this "trade induced acculturation" (Dunaway 1994: 235: 1996a: 38) included alcohol and its attendant social disruption (Richter 1992: 264-68), and cash-wage labor at the forts by individual Senecas and Onondagas. Laboring and land sales for Euroamerican cash became common among the Haudenosaunees by the 1740s (Nammack 1969; Richter 1992: 262), though traditional utilitarian property rights, economic redistribution and their decentralized political structure narrowed any inequalities that arose (Richter 1992: 263). While Britain did not yet physically control their homeland (Shannon 1996: 32), by the 1750s the Haudenosaunees were nominally incorporated (Richter 1992: 255-56; cf. Carlson 2001: 249, 2002: 431-32). "Effective incorporation" came in the 1780 s via military force (Hall 1989: 19; cf. Dunaway 1996a: 17; Mintz 1999; Carlson 2001: 248; 2012a: 91). To the extent that incorporation of North American indigenous peoples has never quite ended (Bush 2005: 99-100), the Haudenosaunees have continued to struggle into the present, both legally and otherwise, with the U.S. and Canadian governments over their sovereignty and land rights (Fenelon 2012: 309; Taub 2013).

The Franco-Indigenous PGNs also deteriorated in the $1720 \mathrm{~s}-1750 \mathrm{~s}$, partly because post commanders and senior colonial officials overcharged indigenous fur traders for manufactured goods, rather than suppressing prices for geopolitical reasons (Eccles 1983b: 146). As fur's commodity frontier extended outward (cf. Moore 2000), shipping costs rose between Montreal and the increasingly distant western posts (Innis 1970: 82-83, 100; Eccles 1983b: 147; Egnal 1998: 161). Effectively isolated from competition, each post could operate as a monopoly (Wien 
1990: 316). French Colonial officials then proceeded to restructure the trade in their favor. Much of the "capital and commercial expertise" had come from Montreal merchants and traders, whose profits were taxed by the colonial state, which supported and administered the trade and in turn paid the lease holding post commanders (Wien 1990: 295) - though arguably it was as much about the colonial state skimming revenues from an activity others saw as politically important (Wien 1990: 317). Indeed, these military traders raised their own companies, largely comprised of their own relatives - ergo the trade fell under the control of a small number of wealthy families, who basically became "a military and commercial colonial aristocracy" (Eccles 1983b: 147). Toward the end, the Franco-Indigenous PGN was costing Versailles more to maintain the colony than it was returning to France (Innis 1970: 110; Desbarats 1995: 629).

Even with increasing royal expenditures, Canada's relatively few French settlers could not permanently resist British conquest - nor did certain of them have much desire to, e.g. Montreal merchants who appreciated the freer trade within the British Empire (Choquette 2002: 202), echoing New Netherland's capitulation nearly a century earlier. France's attempt to change its colonial praxis in North America provided too little in terms of Eurocanadian demographic and economic growth relative to the burgeoning British colonies. Like the Dutch found out in the $17^{\text {th }}$ century, a mercantile colonial strategy based on prestige goods trade was vulnerable to competing core powers. And like New Netherland's commercial interests in the $1600 \mathrm{~s}$, Montreal's fur traders saw the advantages of being in Britain's imperial PMN, which gave them access to both British capital and fur's receding commodity frontier (Innis 1970: 149-280; Eccles 1983b: 187, 190; Hornsby 2005: 220-22). U.S. independence enhanced the Montreal advantage by splitting the PMN with an international border that locked out Albany's remaining fur traders from Canada (Innis 1970: 221), as the flexible relationships fostered by PGNs located in a contested periphery gave way to the formalized international boundaries of PMNs (cf. Carlson 2001: 245-46; 2012a: 92; Hall 2013: 45).

\section{Nested Interaction Networks and Contested Peripheries in North America and Elsewhere}

Examining a timespace of the modern world-system, this paper uses a more generalized, statebased definition of contested periphery than is used by those more typically examining earlier, non-capitalist/tributary world-systems. Recognizing that a contested periphery can exist between states as well as between entire world-systems allows it to remain a useful concept in the MWS's post-1500 timespaces. Similar to (if perhaps not entirely synonymous with) frontiers and what Hall (2009: 35) calls "zones of incorporation," contested peripheries are places that show the limits of both core state capacity and indigenous resistance: northeastern North America witnessed the Anglo-French hegemonic struggle, as well as inter-indigenous struggles to access land, fur resources, and European manufactured goods and in turn struggle to maintain autonomy, or at least negotiate their incorporation into the world-economy.

The struggle over the contested periphery of mainland eastern North America was a result of a prestige good helping hook European powers into a region that was still largely a "zone of ignorance," and then priming the region's indigenous peoples by involving them in a PGN (cf. Carlson 2012a: 88), the profitability of which was largely due to relatively cheap indigenous labor in both fur-getting and fur preparation and indigenous knowledge of water transport routes through the interior. Following on from Carlson $(2001 ; 2002 ; 2011 a ; 2012 b)$, this paper has tried to illustrate the dynamic role prestige goods can play, with both European and indigenous powers attempting to harness PGNs for political-military purposes. 
Again, this deviates from the ideal-typical nested interaction networks model, with the BGN included in a PMN, overarched in turn by the PGN, with an IN at the widest geographical scale (Chase-Dunn and Hall 1997: 54; Carlson 2001: 245). Yet Carlson (2002; 2012b: 37-74) also finds nested interaction networks in Russia's fur trade-led expansion across Siberia and into North America showing that this process also seemed to have prestige goods exchange as within, or at least coterminous with, an expanding PMN. This was most apparent in Russian North America. The state explicitly controlled the process during 1700-1743, "roughly" posited as part of an IN, followed by a closely state-regulated period of private enterprise (1743-1799) identified as a PGN, which in turn subsumed a third phase (1753-1795), when the Russian state was compelled to send expeditions to defend its territorial claims: a PMN (Carlson 2002: 402-05). Based on the Russian state's apparently active involvement in all three phases, we could instead posit that the whole process essentially took place within a PMN, or at least was representative of the Kremlin's attempt to expand its PMN by way of a PGN - though Carlson specifies that "private interests [were] used to fund the exploitation of primarily luxury goods, in place of official political-military expansion on an empire's frontier" (2002: 413, 433; italics in original). Similar to the French, the Dutch, and even at times the British in eastern North America, state interest was at least partly behind PGN processes.

Despite changing post-1760 PMN boundaries, the basic Euro-Indigenous prestige goods trade dynamic in northeastern North America still held as the contested periphery/commodity frontier (cf. Leitner 2005) moved westward, and would be further harnessed to the interest of state. British capital and French Canadian savoir faire, along with access to Hudson's Bay watershed fur supplies, let Montreal merchants outcompete Albany's last few fur traders, and use PGNs to control interior North America (à la the old French strategy), including territory awarded the United States in 1783 (Nettles 1962: 211-12; Innis 1970: 166-262). In response, the U.S. government in the mid-1790s-1822 also mimicked late- $17^{\text {th }}$ to $18^{\text {th }}$-century French strategy, establishing numerous western fur trading posts to sell goods "at cost" to native peoples, by way of maintaining good relations and hopefully keep them from trading with both British traders on the upper Great Lakes and Spanish merchants in the southwest (Nettles 1962: 212-13; Danziger 1979: 63-64). Though unsuccessful due to the higher quality of British trade goods (and ended by private American fur traders' opposition), the U.S. government was clearly using a series of local PGNs to keep territory within its formal PMN.

A further aspect of the PGN-PMN dynamic was from the impact of old world diseases, which were very much part of Euro-Indigenous unequal exchange in North America (Delâge 1993: 85), and of course hastened the European conquest (Crosby 1986: 200; Carlson 2002: 427; Hollis 2005: 121). Indeed, trade-borne disease struck some groups before actual first contact (Trigger 1985: 237-38; Crosby 1986: 203), one of the primary ways external areas have been dramatically altered by the expanding MWS, well in advance of more formal incorporation (cf. Ferguson and Whitehead 1992: 8; Dunaway 1996b: 458; Carlson 2001: 238; 2012a: 88, 93; Hollis 2005: 108). Carlson (2001: 240) also posits that disease transfer is an immediate impact of intersocietal contact, yet then suggests it may be difficult to see the political-economic impacts of luxury trade on involved societies (cf. Dêlage 1993: 88). In this particular timespace, epidemic disease among "virgin soil" (Crosby 1976) Indigenous populations was the underside of the northeastern North American PGNs - hidden in exchange and intercultural contact, a seeming side-effect that was very much a part of a dialectic of trade, local furbearer depletion, and warfare (Jennings 1984: 89). 
Yet the northeast's Indigenous societies were rather different from the northwest's, and per Carlson, "the type of society being incorporated may shape the incorporation process" (2002: 431; also Hollis 2005: 109). Northeastern indigenous societies were mostly reliant on "poorer" environments, hence were generally less wealthy than the Pacific coast Nootkas, with apparently less of a pre-contact "culture of accumulation" (Carlson 2002: 424-25; also Wolf 1997: 184). They were subsequently less hierarchically organized than, for example, the Haudenosaunees and Hurons, multinational confederations in turn comprised of villages and dependent on political consensus (Trigger 1990: 80-96; Richter 1992: 41-49). Still, northeastern native peoples appeared to have an equally high utility for trade goods as the Nootkas, both for prestige (initially) and increasingly for more mundane purposes as they discerned what these new items were good for, becoming increasingly skilled traders in the process (Trigger 1991; Kardulias 2007: 73). Though the Nootkas were perhaps better traders after first contact (Wolf 1997: 185; Carlson 2002: 428-29), contact had a similar negative effect on both regions: disease killed many; the gender division of labor was reoriented as male economic activity shifted from food hunting to fur hunting, which increased famine risk; firearms were introduced, leading to increased inter-indigenous conflicts; "traditional power structures" were "destabilized"; and the fur bearing mammals on which the PGNs depended became locally extinct (Carlson 2002: 42627, 429-30, 435). But while the Nootkas caught the Europeans' attention with a profitable prestige good that allowed for "the initial 'hooking' of [the] arena to the world-system" (Carlson 2002: 410), they were not a geopolitically indispensable military ally like the Haudenosaunees to the British or the Ottawas to the French.

Northeastern North America's PGN-PMN dynamic actually had more in common with what Carlson (2011b; 2012b: 75-114) finds in West Africa. The inland Asante kingdom, in what is now Ghana, acquired firearms from Dutch (the GWC, in fact) and Danish traders (also Wolf 1997: 208-16) and expanded into neighboring territory, reaching for the coast and direct contact with the Europeans (Carlson 2011b: 16, 37-42). Asante thereby both defeated and circumvented the coastal states that previously controlling the trade, but ran afoul of the British interest in keeping West Africans politically fragmented and competing with each other (Carlson $2011 \mathrm{~b}$ : 17). Similar to the Haudenosaunees' experience, for the Asante ca. 1700-50 European-supplied firearms were a key tool for both prosecuting a PGN and expanding their PMN (Wolf 1997: 212; Carlson 2011b: 37). A major difference was a reversed disease vector; in part because they were less isolated from Eurasia, Africans were typically much less susceptible to Eurasian diseases than were Indigenous Americans, while Europeans experienced high mortality rates from African diseases (Crosby 1986: 138-39, 286). The Asante were therefore able to develop and engage in state-building and expansion in the $18^{\text {th }}$ century without direct European interference (Carlson 2011b: 47).

But however important prestige goods may have been to the MWS's spatial expansion, it is bulk goods production and trade that allows for ascent up the world-system hierarchy and arguably has had a spatially-expansive dynamic of its own, both in terms of the quest for more and cheaper raw material inputs (Bunker and Ciccantell 2005) and the quest to overcome the local ecological crises upon which capitalist production is based (Moore 2011). Europeans were attracted to the Americas as much by cod, timber, and fertile soil as by furs and precious metals (Richards 2003: 309-516, 547-73). Even where prestige goods were initially important to attracting European attention and colonization, making the PGN-to-BGN transition has proven more important for those colonies' - and their indigenous neighbors' - geopolitical futures in the MWS. 


\section{Acknowledgements}

The author heartily thanks the two anonymous $J W S R$ reviewers for their helpful suggestions and insightful comments.

\section{References}

Abler, Thomas S. 1992. "Beavers and Muskets: Iroquois Military Fortunes in the Face of European Colonization." Pp. 151-174 in War in the Tribal Zone: Expanding States and Indigenous Warfare, edited by R. Brian Ferguson and Neil L. Whitehead. Santa Fe: School of American Research Press.

Abu-Lughod, Janet L. 1989. Before European Hegemony: The World System A.D. 1250-1350. New York: Oxford University Press.

Adelman, Jeremy and Stephen Aron. 1999. "From Borderlands to Borders: Empires, NationStates, and the Peoples in Between in North American History." American Historical Review 104: 814-841.

Aquila, Richard. 1983. The Iroquois Restoration: Iroquois Diplomacy on the Colonial Frontier, 1701-1754. Detroit: Wayne State University Press.

Bachman, Van Cleaf. 1969. Peltries or Plantations: The Economic Policies of the Dutch West India Company in New Netherland, 1623-1639. Baltimore: Johns Hopkins University Press.

Baker, Emerson and John G. Reid. 2004. "Amerindian Power in the Early Modern Northeast: A Reappraisal." William and Mary Quarterly 61: 77-106.

Boxer, C.R. 1990 [1965]. The Dutch Seaborne Empire, 1600-1800. London: Penguin Books.

Brandão, José António. 1997. "Your Fyre Shall Burn No More": Iroquois Policy toward New France and Its Native Allies to 1701. Lincoln: University of Nebraska Press.

Brandão, J.A. and William A. Starna. 1996. "The Treaties of 1701: A Triumph of Iroquois Diplomacy." Ethnohistory 43: 210-245.

Brenner, Robert. 2003 [1993]. Merchants and Revolution: Commercial Change, Political Conflict, and London's Overseas Traders, 1550-1653. London: Verso.

Buffinton, Arthur H. 1922. "The Policy of Albany and English Westward Expansion." Mississippi Valley Historical Review 8: 327-366.

Bumsted, J.M. 1992. The Peoples of Canada: A Pre-Confederation History. Toronto: Oxford University Press.

Bunker, Stephen G., and Paul S. Ciccantell. 2005. Globalization and the Race for Resources. Baltimore: Johns Hopkins University Press.

Burke, Thomas E., Jr. 1991. "The New Netherland Fur Trade, 1657-1661: Response to Crisis." Pp. 283-291 in A Beautiful and Fruitful Place: Selected Rensselaerswijck Seminar Papers, edited by in Nancy A. McClure Zeller. Albany, NY: New Netherland Publishing.

Burrows, Edwin G. and Mike Wallace. 1999. Gotham: A History of New York City to 1898. New York: Oxford University Press.

Bush, Caleb M. 2005. "Reconsidering Incorporation: Uneven Histories of Capitalist Expansion 
and Encroachment, Native America." Studies in Political Economy 76: 83-109.

Carlson, Jon D. 2001. "Broadening and Deepening: Systemic Expansion, Incorporation and the Zone of Ignorance." Journal of World-Systems Research 7: 225-263.

2002. "The 'Otter-Man' Empires: The Pacific Fur Trade, Incorporation and the Zone of Ignorance." Journal of World-Systems Research 8: 390-442.

-----. 2011a. "Externality and Incorporation in the World-System: Abyssinia - Anomaly or Palimpsest?" Journal of World-Systems Research 17: 165-198.

-----. 2011b. "West Africa \& the Rise of Asante: Rivers of (Black) Gold and the Protoglobalization of Labor." Paper presented at the American Sociological Association Annual Meeting, Las Vegas.

-----. 2012a. "Externality, Contact Periphery \& Incorporation." Pp. 87-96 in Routledge Handbook of World-Systems Analysis, edited by Salvatore J. Babones and Christopher Chase-Dunn. New York: Routledge.

-----. 2012b. Myths, State Expansion, and the Birth of Globalization: A Comparative Perspective. New York: Palgrave Macmillan.

Ceci, Lynn. 1990. "Native Wampum as a Peripheral Resource in the Seventeenth-Century World-System." Pp. 48-63 in The Pequots in Southern New England: The Fall and Rise of an American Indian Nation, edited by Laurence M. Hauptman and James D. Wherry. Norman: University of Oklahoma Press.

Chase-Dunn, Christopher. 1980. "The Development of Core Capitalism in the Antebellum United States: Tariff Politics and Class Struggle in an Upwardly Mobile Semiperiphery." Pp. 189-203 in Studies of the Modern World-System, edited by Albert J. Bergesen. New York: Academic Press.

Chase-Dunn, Christopher and E.N. Anderson, eds. 2005. The Historical Evolution of WorldSystems. New York: Palgrave Macmillan.

Chase-Dunn, Christopher and Thomas D. Hall. 1997. Rise and Demise: Comparing WorldSystems. Boulder, CO: Westview Press.

----. 2012. "Global Scale Analysis in Human History." Pp. 185-200 in A Companion to World History, edited by Douglas Northrop. Oxford: Wiley-Blackwell.

Choquette, Leslie. 1997. Frenchmen into Peasants: Modernity and Tradition in the Peopling of French Canada. Cambridge, MA: Harvard University Press.

-----. 2002. "Center and Periphery in French North America." Pp. 193-206 in Negotiated Empires: Centers and Peripheries in the Americas, 1500-1820, edited by Christine Daniels and Michael V. Kennedy. New York: Routledge.

Cline, Eric H. 2000. "Contested Peripheries' in World Systems Theory: Megiddo and the Jezreel Valley as a Test Case." Journal of World-Systems Research 6: 7-16.

Condon, Thomas J. 1968. New York Beginnings: The Commercial Origins of New Netherland. New York: New York University Press.

Crosby, Alfred W. 1976. "Virgin Soil Epidemics as a Factor in the Aboriginal Depopulation in America." William and Mary Quarterly 33:289-299.

Crosby, Alfred W. 1986. Ecological Imperialism: The Biological Expansion of Europe, 9001900. Cambridge: Cambridge University Press.

Danziger, Edmund Jefferson, Jr. 1979. The Chippewas of Lake Superior. Norman: University of Oklahoma Press.

Delâge, Denys. 1993. Bitter Feast: Amerindians and Europeans in Northeastern North America, 1600-64. Jane Brierly, trans. Vancouver: UBC Press. 
Denemark, Robert A., Jonathan Friedman, Barry K. Gills, and George Modelski, eds. 2000. World System History: The Social Science of Long-Term Change. New York: Routledge.

Desbarats, Catherine M. 1995. "The Cost of Early Canada's Native Alliances: Reality and Scarcity's Rhetoric." William and Mary Quarterly 52: 609-630.

Dunaway, Wilma A. 1994. "The Southern Fur Trade and the Incorporation of Southern Appalachia into the World-Economy, 1690-1763." Review 17: 215-242.

-----. 1996a. The First American Frontier: Transition to Capitalism in Southern Appalachia, 1700-1860. Chapel Hill: University of North Carolina Press.

-----. 1996b. "Incorporation as an Interactive Process: Cherokee Resistance to Expansion of the Capitalist World-System, 1560-1763." Sociological Inquiry 66: 455-470.

Dunn, Shirley W. 1994. The Mohicans and their Land, 1609-1730. Fleischmanns, NY: Purple Mountain Press.

Earle, Carville. 1992. "Pioneers of Providence: The Anglo-American Experience, 1492-1792." Annals of the Association of American Geographers 82: 478-499.

Eccles, W.J. 1972. France in America. New York: Harper \& Row.

-----. 1983a. "The Fur Trade and Eighteenth-Century Imperialism." William and Mary Quarterly 40: 341-362.

----. 1983b. The Canadian Frontier, 1534-1760. Rev. ed. Albuquerque: University of New Mexico Press.

Egnal, Marc. 1998. New World Economies: The Growth of the Thirteen Colonies and Early Canada. New York: Oxford University Press.

Fenelon, James V. 2012. "Indigenous Peoples, Globalization and Autonomy in World-Systems Analysis." Pp. 304-312 in Routledge Handbook of World-Systems Analysis, edited by Salvatore Babones and Christopher Chase-Dunn. New York: Routledge.

Ferguson, R. Brian and Neil L. Whitehead. 1992. "The Violent Edge of Empire." Pp. 1-30 in War in the Tribal Zone: Expanding States and Indigenous Warfare, edited by R. Brian Ferguson and Neil L. Whitehead. Santa Fe: School of American Research Press.

Fernow, B. 1877-87. Documents Relating to the Colonial History of the State of New York. Vols. 12-15. Albany, NY: Weed, Parsons and Company.

Gehring, Charles T. and William A. Starna. 1992. "Dutch and Indians in the Hudson Valley: The Early Period." Hudson Valley Regional Review 9(2): 1-25.

Greene, Jack P. 2002. "Transatlantic Colonization and the Redefinition of Empire in the Early Modern Era: The British-American Experience." Pp. 267-282 in Negotiated Empires: Centers and Peripheries in the Americas, 1500-1820, edited by Christine Daniels and Michael V. Kennedy. New York: Routledge.

Hagedorn, Nancy L. 1995. "Brokers of Understanding: Interpreters as Agents of Cultural Exchange in Colonial New York." New York History 76: 379-408.

Hall, Thomas D. 1989. Social Change in the Southwest, 1350-1880. Lawrence: University Press of Kansas.

-----. 2005. "Mongols in World-Systems History." Social Evolution \& History 4:89-118.

-----. 2009. "Puzzles in the Comparative Study of Frontiers: Problems, Some Solutions, and Methodological Implications." Journal of World-Systems Research 15: 25-47.

----. 2012. "Incorporation into and Merger of World-Systems." Pp. 47-55 in Routledge Handbook of World-Systems Analysis, edited by Salvatore Babones and Christopher Chase-Dunn. New York: Routledge.

-----. 2013. "Lessons from Comparing the Two Southwests: Southwest China and Northwest 
New Spain/Southwest United States." Journal of World-Systems Research 19:24-56.

Hall, Thomas D. and P. Nick Kardulias. 2010. "Human Migration Over Millenia: A WorldSystems View of Human Migration, Past and Present." Pp. 22-37 in Mass Migration in the World-System: Past, Present and Future. Political Economy of the World-System Annual, Vol. 31, edited by Terry-Ann Jones and Eric Mielants. Boulder, CO: Paradigm Press.

Harris, R. Cole and John Warkentin. 1974. Canada Before Confederation: A Study in Historical Geography. New York: Oxford University Press.

Hollis, Shirley A. 2005. "Contact, Incorporation, and the North American Southeast." Journal of World-Systems Research 11: 95-130.

Hopkins, Terence K. and Immanuel Wallerstein. 1987. "Capitalism and the Incorporation of New Zones into the World-Economy." Review 10: 763-779.

Hornsby, Stephen J. 2005. British Atlantic, American Frontier: Spaces of Power in Early Modern British America. Hanover, NH: University Press of New England.

Howard, Ronald W. 2001. "The English Province (1664-1776)." Pp. 113-228 in The Empire State: A History of New York, edited by Milton M. Klein. Ithaca, NY: Cornell University Press.

Innis, Harold A. 1956. Essays in Canadian Economic History. Mary Q. Innis, ed. Toronto: University of Toronto Press.

-----. 1970. The Fur Trade in Canada: An Introduction to Canadian Economic History. Rev. ed. Toronto: University of Toronto Press.

Jacobs, Jaap. 2005. New Netherland: A Dutch Colony in Seventeenth-Century America. Leiden: Brill.

Jennings, Francis. 1984. The Ambiguous Iroquois Empire: The Covenant Chain Confederation of Indian Tribes with English Colonies from its beginnings to the Lancaster Treaty of 1744. New York: W.W. Norton \& Co.

Kammen, Michael. 1975. Colonial New York: A History. New York: Charles Scribner's Sons.

Kardulias, P. Nick. 1990. "Fur Production as a Specialized Activity in a World System: Indians in the North American Fur Trade." American Indian Culture and Research Journal 14: 25-60.

-----. 2007. "Negotiation and Incorporation on the Margins of World-Systems: Examples from Cyprus and North America." Journal of World-Systems Research 13: 55-82.

Klooster, Wim. 2002. "Other Netherlands Beyond the Sea: Dutch America between Metropolitan Control and Divergence, 1600-1795." Pp. 171-191 in Negotiated Empires: Centers and Peripheries in the Americas, 1500-1820, edited by Christine Daniels and Michael V. Kennedy. New York: Routledge.

Kraft, Herbert C. 1986. The Lenape: Archaeology, History, and Ethnography. Newark: New Jersey Historical Society.

Lanctôt, Gustave. 1965. A History of Canada. Vol. 3: From the Treaty of Utrecht to the Treaty of Paris, 1713-1763. Cambridge, MA: Harvard University Press.

Leitner, Jonathan. 2005. "Commodity Frontier as Contested Periphery: The Fur Trade in Iroquoia and New York, 1664-1754." Pp. 231-252 in Research in Rural Sociology and Development. Vol. 10: Nature, Raw Materials, and Political Economy, edited by Paul Ciccantell, David A. Smith and Gay Seidman. Amsterdam: JAI/Elsevier Science.

McMichael, Phillip. 1990. "Incorporating Comparison within a World-Historical Perspective: An Alternative Comparative Method." American Sociological Review 55: 385-397. 
-----. 2000. "World-Systems Analysis, Globalization, and Incorporated Comparison." Journal of World-Systems Research 6: 668-699.

Mancall, Peter C., Joshua L. Rosenbloom, and Thomas Weiss. 2002. "The Economic Activity of Native Americans in British North America." Paper presented at the $13^{\text {th }}$ World Congress in Economic History, Buenos Aires.

Matson, Cathy. 1998. Merchants \& Empire: Trading in Colonial New York. Baltimore: Johns Hopkins University Press.

Meuwese, Marcus P. 2003. "For the Peace and Well-Being of the Country': Intercultural Mediators and Dutch-Indian Relations in New Netherland and Dutch Brazil, 1600-1664." Unpublished Ph.D. dissertation, University of Notre Dame.

Mintz, Max M. 1999. Seeds of Empire: The American Revolutionary Conquest of the Iroquois. New York: New York University Press.

Miquelon, Dale. 1988. "Canada's Place in the French Imperial Economy: An Eighteenth-Century Overview." French Historical Studies 15: 432-443.

Moogk, Peter N. 1989. "Reluctant Exiles: Emigrants from France in Canada before 1760." William and Mary Quarterly 46: 463-505.

-----. 2000. La Nouvelle France: The Making of French Canada--A Cultural History. East Lansing: Michigan State University Press.

Moore, Jason W. 2000. "Sugar and the Expansion of the Early Modern World-Economy: Commodity Frontiers, Ecological Transformation, and Industrialization." Review 23: 409-433.

-----. 2011. "Transcending the Metabolic Rift: A Theory of Crises in the Capitalist-World Ecology." Journal of Peasant Studies 38: 1-46.

Nammack, Georgiana C. 1969. Fraud, Politics, and the Dispossession of the Indians: The Iroquois Land Frontier in the Colonial Period. Norman: University of Oklahoma Press.

Nettles, Curtis P. 1962. The Economic History of the United States. Volume II: The Emergence of a National Economy, 1775-1815. New York: Holt, Rinehart and Winston.

Norton, Thomas E. 1974. The Fur Trade in Colonial New York, 1686-1776. Madison: University of Wisconsin Press.

O'Callaghan, E.B., ed. 1853-61. Documents Relative to the Colonial History of the State of NewYork. Vols. 1-11. Albany, NY: Weed, Parsons and Company.

Özveren, Y. Eyüp. 2000. "Shipbuilding, 1590-1790." Review 23: 15-86.

Pares, Richard. 1968 [1956]. Yankees and Creoles: The Trade between North America and the West Indies before the American Revolution. Hamden, CT: Archon Books.

Richards, John F. 2003. The Unending Frontier: An Environmental History of the Early Modern World. Berkeley: University of California Press.

Richter, Daniel K. 1983. "War and Culture: The Iroquois Experience." William and Mary Quarterly 40: 528-559.

-----. 1988. "Cultural Brokers and Intercultural Politics: New York-Iroquois Relations, 16641701." Journal of American History 75: 40-67.

-----. 1992. The Ordeal of the Longhouse: The Peoples of the Iroquois League in the Era of European Colonization. Chapel Hill: University of North Carolina Press.

-----. 2001. Facing East from Indian Country: A Native History of Early America. Cambridge, MA: Harvard University Press.

Rink, Oliver A. 1986. Holland on the Hudson: An Economic and Social History of Dutch New York. Ithaca, NY: Cornell University Press. 
Schlesier, Karl H. 1976. "Epidemics and Indian Middlemen: Rethinking the Wars of the Iroquois, 1609-1653." Ethnohistory 23: 129-145.

Shannon, Timothy J. 1996. "Dressing for Success on the Mohawk Frontier: Hendrick, William Johnson, and the Indian Fashion." William and Mary Quarterly 53: 13-42.

Snow, Dean R. and Kim M. Lanphear. 1988. "European Contact and Indian Depopulation in the Northeast: The Timing of the First Epidemics." Ethnohistory 35: 15-33.

Starna, William A. 1991. "Seventeenth Century Dutch-Indian Trade: A Perspective from Iroquoia." Pp. 243-249 in A Beautiful and Fruitful Place: Selected Rensselaerswijck Seminar Papers, edited by Nancy A. McClure Zeller. Albany, NY: New Netherland Publishing.

Starna, William A. 2003. "Assessing American Indian-Dutch Studies: Missed and Missing Opportunities." New York History 84: 5-31.

Starna, William A. and José António Brandão. 2004. "From the Mohawk-Mahican War to the Beaver Wars: Questioning the Pattern." Ethnohistory 51: 725-750.

Taub, Julian. 2013. "The Iroquois Are Not Giving Up." The Atlantic. August.

Thomas, Peter A. 1981. "The Fur Trade, Indian Land and the Need to Define Adequate 'Environmental' Parameters." Ethnohistory 28: 359-379.

Trelease, Allen W. 1962. "The Iroquois and the Western Fur Trade: A Problem in Interpretation." Mississippi Valley Historical Review 49: 32-51.

-----. 1997 [1960]. Indian Affairs in Colonial New York: The Seventeenth Century. Lincoln: University of Nebraska Press.

Trigger, Bruce G. 1971. "The Mohawk-Mahican War (1624-28): The Establishment of a Pattern." Canadian Historical Review 52: 276-286.

-----. 1985. Natives and Newcomers: Canada's 'Heroic Age' Reconsidered. Montreal and Kingston, ON: McGill-Queen's University Press.

-----. 1990. The Huron: Farmers of the North. 2nd ed. Fort Worth, TX: Holt, Rinehart and Winston, Inc.

-----. 1991. "Early Native North American Responses to European Contact: Romantic versus Rationalistic Interpretations." Journal of American History 77: 1195-1215.

Wallerstein, Immanuel. 1980. The Modern World-System II: Mercantilism and the Consolidation of the European World-Economy, 1600-1750. New York: Academic Press.

----- 2004. World-Systems Analysis: An Introduction. Durham, NC: Duke University Press.

Wien, Thomas. 1990. "Selling Beaver Skins in North America and Europe, 1720-1760: The Uses of Fur-Trade Imperialism." Journal of the Canadian Historical Association 1: 293-317.

Wolf, Eric R. 1997 [1982]. Europe and the People Without History. Berkeley: University of California Press. 